\title{
Insights into xanthomonas axonopodis pv. citri biofilm through proteomics
}

\author{
Tamara Zimaro', Ludivine Thomas², Claudius Marondedze², Betiana S Garavaglia', Chris Gehring², \\ Jorgelina Ottado ${ }^{1}$ and Natalia Gottig ${ }^{1 *}$
}

\begin{abstract}
Background: Xanthomonas axonopodis pv. citri (X. a. pv. citri) causes citrus canker that can result in defoliation and premature fruit drop with significant production losses worldwide. Biofilm formation is an important process in bacterial pathogens and several lines of evidence suggest that in X. a. pv. citri this process is a requirement to achieve maximal virulence since it has a major role in host interactions. In this study, proteomics was used to gain further insights into the functions of biofilms.

Results: In order to identify differentially expressed proteins, a comparative proteomic study using 2D difference gel electrophoresis was carried out on X. a. pv. citri mature biofilm and planktonic cells. The biofilm proteome showed major variations in the composition of outer membrane proteins and receptor or transport proteins. Among them, several porins and TonB-dependent receptor were differentially regulated in the biofilm compared to the planktonic cells, indicating that these proteins may serve in maintaining specific membrane-associated functions including signaling and cellular homeostasis. In biofilms, UDP-glucose dehydrogenase with a major role in exopolysaccharide production and the non-fimbrial adhesin YapH involved in adherence were over-expressed, while a polynucleotide phosphorylase that was demonstrated to negatively control biofilm formation in E. coli was down-regulated. In addition, several proteins involved in protein synthesis, folding and stabilization were up-regulated in biofilms. Interestingly, some proteins related to energy production, such as ATP-synthase were down-regulated in biofilms. Moreover, a number of enzymes of the tricarboxylic acid cycle were differentially expressed. In addition, $X . a$. pv. citri biofilms also showed down-regulation of several antioxidant enzymes. The respective gene expression patterns of several identified proteins in both X. a. pv. citri mature biofilm and planktonic cells were evaluated by quantitative real-time PCR and shown to consistently correlate with those deduced from the proteomic study.

Conclusions: Differentially expressed proteins are enriched in functional categories. Firstly, proteins that are downregulated in X. a. pv. citri biofilms are enriched for the gene ontology (GO) terms 'generation of precursor metabolites and energy' and secondly, the biofilm proteome mainly changes in 'outer membrane and receptor or transport'. We argue that the differentially expressed proteins have a critical role in maintaining a functional external structure as well as enabling appropriate flow of nutrients and signals specific to the biofilm lifestyle.
\end{abstract}

Keywords: Xanthomonas axonopodis pv. citri, Citrus canker, Biofilm, Proteomics

\footnotetext{
* Correspondence: gottig@ibr-conicet.gov.ar

'Instituto de Biología Molecular y Celular de Rosario, Consejo Nacional de Investigaciones Científicas y Técnicas (IBR-CONICET), Ocampo y Esmeralda, Rosario, Santa Fe, Argentina

Full list of author information is available at the end of the article
}

\section{Biomed Central}

(c) 2013 Zimaro et al.; licensee BioMed Central Ltd. This is an Open Access article distributed under the terms of the Creative Commons Attribution License (http://creativecommons.org/licenses/by/2.0), which permits unrestricted use, distribution, and reproduction in any medium, provided the original work is properly cited. 


\section{Background}

Xanthomonas axonopodis pv. citri (X.a. pv. citri) is a gram-negative plant pathogenic bacteria that causes citrus canker [1]. This phytopathogen invades host plant tissues entering through stomata or wounds and then colonizes the apoplast of fruits, foliage and young stems and symptoms of infection appear as raised corky lesions. At the final stage, plant tissue epidermis is broken due to cell hyperplasia, which allows bacterial dispersal to other plants by windblown rain. Persistent and severe disease can lead to defoliation, dieback and fruit drop thereby reducing yields, and hence causing serious economic losses. Moreover, quarantine restrictions are imposed to producing areas with citrus canker thus hampering commercialization of fresh fruit [2].

In most environments, bacteria primarily grow in association with surfaces, leading to the formation of biofilms. These biofilms generally consist of microbial cells attached to a surface and covered with an extracellular matrix composed of protein and polysaccharides [3]. The elevated population density forming a biofilm can increase biological processes that single cells cannot perform. Specifically, the biofilm lifestyle can offer increased protection against environmental stresses and increase bacterial resistance against host defense responses and antimicrobial tolerance. Biofilms also allow for consortial metabolism and may increase the possibility for horizontal gene transfer [3]. For most pathogenic bacteria, attachment to surfaces and successive biofilm formation are essential steps in the development of chronic infections and maintenance on host tissues [4]. In plant pathogens, biofilm formation also allows for increased bacterial cell density that in turn helps to achieve a critical mass of cells at a specific location to initiate and sustain interactions with host plants [5].

$X$. a. pv. citri biofilm formation appears to be a common feature during infection and different $X . a$. pv. citri mutants impaired in surface attachment, aggregation and hence in biofilm formation are also deficient in pathogenesis [6-8]. The lack of exopolysaccharide (EPS), the main component of the matrix surrounding biofilm cells, reduces epiphytic survival in planta [9] and has a negative impact on $X$. a. pv. citri virulence [10-14]. Other mutant strains affected in lipopolysaccharide (LPS) or glucan biosynthesis are impaired in the formation of structured biofilms and show reduced virulence symptoms [15-17]. Moreover, the two-component regulatory system ColR/ColS, which plays a major role in the regulation of $X . a$. pv. citri pathogenicity, also modulates biofilm formation [18]. In this context, further insight into $X$. a. pv. citri biofilm formation was gained by screening $X$. $a$. pv. citri transposon insertion mutants for biofilm-defective phenotypes, leading to the identification of several genes related to $X$. a. pv. citri biofilm formation [19]. Given that for X. a. pv. citri too, biofilm formation is a requirement to achieve maximal virulence, we have used proteomics to identify differentially expressed proteins with a view to gain further insight into the process of biofilm formation.

\section{Results and discussion}

Phenotypic analysis of $X$. a. pv. citri biofilm development

Biofilm formation generally requires a number of different processes including the initial surface attachment of cells, cell multiplication to form micro-colonies and maturation of the biofilm [20]. For a better understanding of the dynamics of this process in $X . a$. pv. citri, biofilm structure of a GFP-expressing $X$. a. pv. citri strain (Xac-GFP) was observed at different growth stages by confocal laser scanning microscopy. To this end, XacGFP was cultured in static liquid XVM2 medium, a minimal medium that mimics the nutritional conditions found in plant tissues [21]. As previously described, biofilms are important for $X$. $a$. pv. citri virulence, and thus XVM2 medium was used to analyze bacterial biofilm formation in a plant-like environment. After one day of growth, some cells began to attach to the surface of the PVC plate wells, however, the majority of cells remained dispersed in the culture medium (Figure 1). After three days of growth, cells initiated accumulation and formation of a biofilm (Figure 1), and after seven days, Xac-GFP cells formed a distinctly structured and dense biofilm consisting of large cell aggregations separated by a network of large channels (Figure 1) that ensured appropriate micronutrient and oxygen fluxes [22]. We also evaluated the population size of these biofilms and observed that at day seven of growth the biofilms reached a maximum population size of $1 \times 10^{9} \mathrm{cfu} / \mathrm{ml}$. In a planktonic culture in XVM2 medium, a similar maximal population size is reached in early stationary phase. Therefore, these two conditions of growth were used to identify differentially expressed proteins between the two lifestyles at their respective maximum population sizes and prior to the occurrence of noticeable cell death.

Two-dimensional gel electrophoretic analysis of protein expression and mass spectrometric identification of the $X . a$. pv. citri biofilm proteome

Since proteomics is a powerful method to obtain systems information on the physiology of bacterial cells, we aimed at analyzing and characterizing mature biofilms of $X$. a. pv. citri, and compare the proteome to that of planktonic $X . a$. pv. citri cells. Total proteins of these cultures were extracted and separated by two-dimensional gel electrophoresis (2-DE) (see "Methods" section). Protein extractions were performed from three independent biological samples, and two technical replicate gels for each cell type were compared. A total of 46 protein spots 

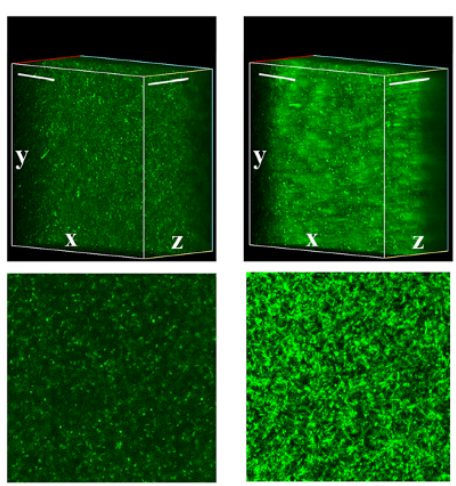

1 Day

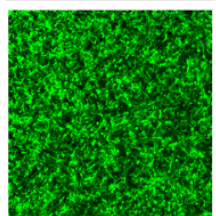

3 Days
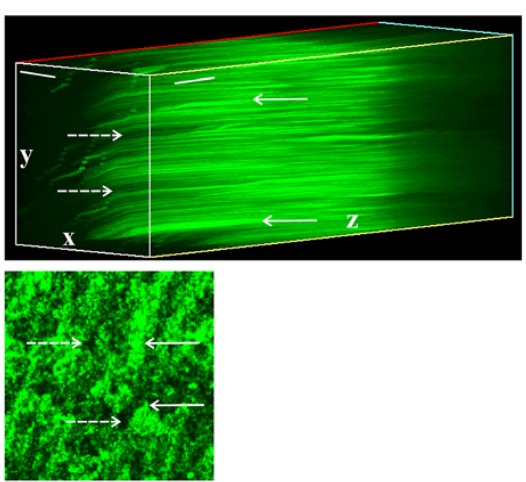

7 Days

Figure 1 Confocal laser scanning microscopy analysis $\boldsymbol{X}$. $\boldsymbol{a}$. pv. citri in vitro biofilms. Representative photographs of laser scanning confocal analysis of GFP-expressing X. a. pv. citri cells cultured in static liquid XVM2 in 24-well PVC plates for one, three and seven days (upper panels). Serial images were taken at $0.5 \mu \mathrm{m}$ distances (z-stack). White arrows point to cell aggregations and dotted white arrows point to network channels. Scale bars: $30 \mu \mathrm{m}$. For a better visualization, the lower panels are images of biofilm channels and cell aggregates at 7 days.

were differentially regulated (Figure 2), excised and processed for analysis by mass spectrometry. Forty-one spots were identified, corresponding to a total of 53 proteins (Additional file 1: Table S1), while five spots (spots 250, 382, 348, 352 and 357) remained unidentified, probably due to the very low protein concentration in these spots. Some protein spots were assigned to more than one protein, possibly because the proteins co-migrated as a result of having the same $\mathrm{p} I$ and molecular weight. This pattern of co-migration is not uncommon in proteomic studies and was reported previously $[23,24]$. The 31 upand 22 down-regulated $X . a$. pv. citri biofilm proteins were classified into different categories based on their functions [25] (Additional file 1: Table S1). The protein spot displaying the strongest up-regulation was $50 \mathrm{~S}$ ribosomal protein L4 (XAC0973; +5.1 fold; spot 79), followed by TonB-dependent receptor (XAC3489; +4.9 fold; spot 168), while the protein spot with the most pronounced down-regulation was an ATP synthase beta chain (XAC3649; -10.7 fold; spot 76). Here we focus on interpreting a subset (see Table 1) of the differentially expressed biofilm proteins.

Functional characterization of differentially regulated $X$. a. pv. citri biofilm proteins

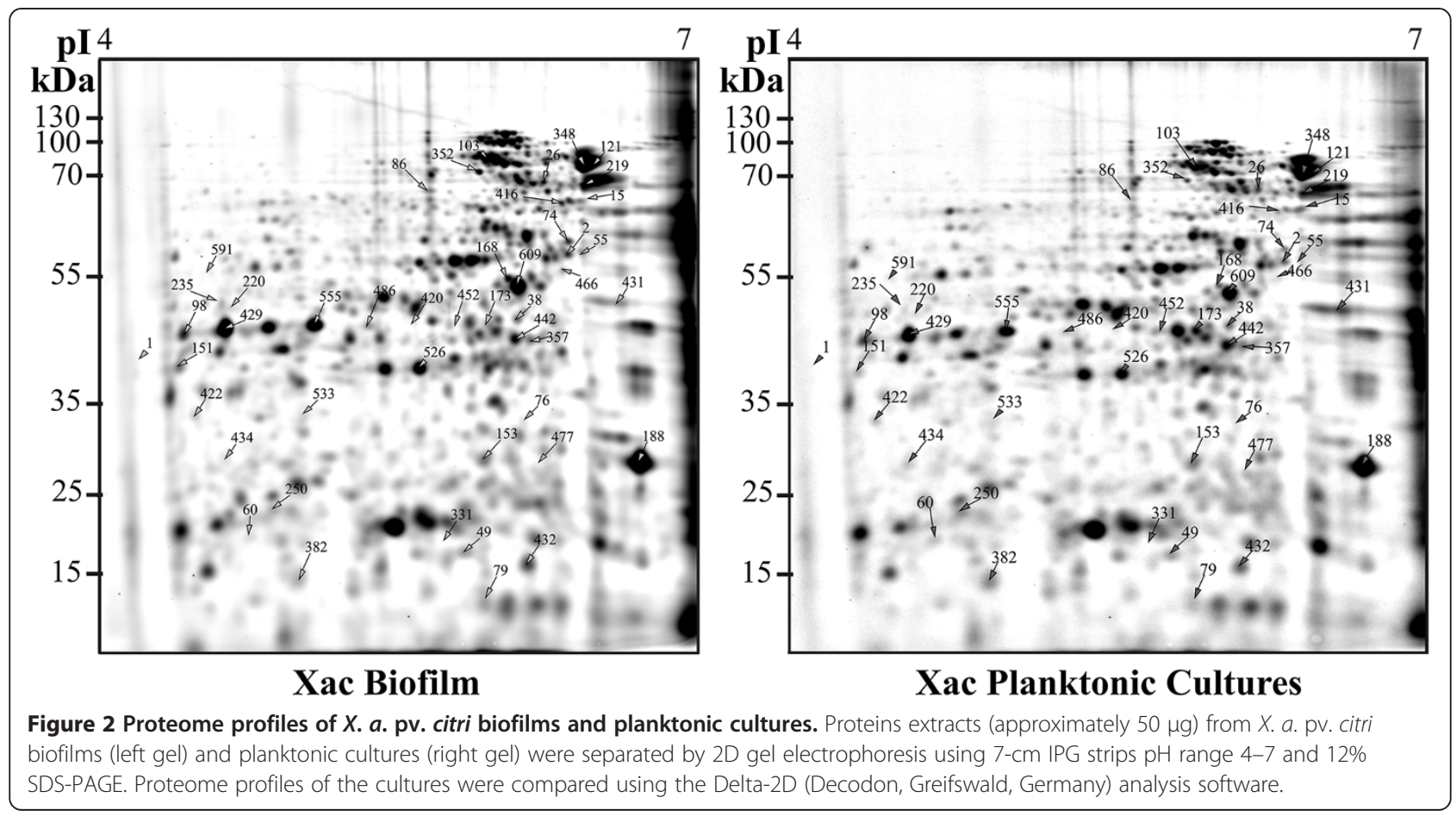


Table 1 Selected proteins differentially expressed during $X . a . p v$. citri biofilm formation

\begin{tabular}{ll}
$\begin{array}{l}\text { Spot Protein name } \\
\text { no. }\end{array}$ & $\begin{array}{l}\text { MOWSE } \\
\text { score }\end{array}$ \\
\hline 01 Metabolism & \\
01.02 Nitrogen, sulfur and selenium metabolism \\
01.02 .02 Nitrogen metabolism
\end{tabular}

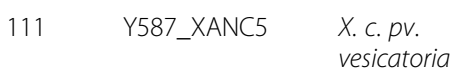

XAC0554 21.0/5.83 20.0/4.6 $\quad 7 / 31 \%$

$-5.6$

01.05 C-compounds and carbohydrate metabolism

220 UDP-glucose dehydrogenase 125

Q8PGN5_XANAC X.a.pv. citri

XAC3581 $43.1 / 6.18 \quad 68.0 / 6.7 \quad 13 / 25 \%$

$+2.6$

01.06 Lipid, fatty acid and isoprenoid metabolism

01.06.02 Membrane lipid metabolism

609 Outer membrane protein (FadL)

1070

Q8PRE4_XANAC X.a.pv. citri

XAC0019 47.3/5.18 54.0/6.0 54/40\%

$+2.6$

01.20 Secondary metabolism

533 Coproporphyinogen-III oxidase, 191 aerobic

HEM6_XANAC X.a.pv. citri

XAC4109 $34.6 / 5.8$

48.0/5.4 11/30\%

$-1.5$

434 Short chain dehydrogenase 141

Q8PME5_XANAC X.a.pv. citri

XAC1484 26.0/5.97

29.0/4.5

$14 / 34 \%$

$-5.1$

02 Energy

02.04 Glyoxylate cycle

331 KDPG and KHG aldolase 163

02.10 Tricarboxylic-acid pathway

$\begin{array}{ll}98 & \text { Malate dehydrogenase } \\ 121 & \begin{array}{l}\text { Dihydrolipoamide } \\ \text { S-succinyltransferase }\end{array} \\ 235 & \text { Citrate synthase } \\ 591 & \begin{array}{l}\text { Succinate dehydrogenase } \\ \text { flavoprotein subunit }\end{array}\end{array}$

63

Q8PKU5_XANAC X.a.pv.citri

XAC2067 22.9/5.24

$23.0 / 4.8$

$7 / 31 \%$

$-2.0$

905

MDH_XANAC X.a.pv. citri

XAC1006 34.9/5.37

48.0/4.3 $\quad 46 / 51 \%$

$+1.5$

36

Q3BVA5 XANC5

XAC1534 42.4/5.87

$69.0 / 6.5$

$9 / 10 \%$

$+1.8$

218

Q3BPS8_XANC5 vesicatoria

XAC3388 $\quad 47.9 / 5.97$

$68.0 / 6.6$

$8 / 20 \%$

$+2.6$

206

vesicatoria

Q3BTD_XANC5

X.c.pv.

XAC2077 65.8/5.89 55.0/4.4

$18 / 22 \%$

vesicatoria

02.45 Energy conversion and regeneration

02.45.15 Energy generation

$\begin{array}{ll}76 & \text { ATP synthase beta chain } \\ 442 & \text { Phosphoglycerate kinase } \\ 422 & \begin{array}{l}\text { NADH-ubiquinone } \\ \text { oxidoreductase }\end{array}\end{array}$

72

Q2P7Q4 XANOM $x$. 0.pv.

$32.0 / 6.1$

$3 / 8 \%$

XAC3347 40.9/4.91

$45.0 / 6.0$

$47 / 43 \%$

$-1.9$

40 Q3BRN4_XANC5

X.c.pv.

XAC2699 48.8/6.32

$33.0 / 4.4$

$8 / 18 \%$

$-3.9$

11 Transcription

11.04 RNA processing

153 Polynucleotide phosphorylase

12 Protein synthesis

12.01 Ribosome biogenesis

79505 ribosomal proten

12.04 Translation

26 Elongation factor Tu

$\begin{array}{lll}133 & \text { AAM35856 } & \text { X.a.pv.citri } \\ 294 & \text { Q3BWY6_XANC5 } & \begin{array}{l}\text { X.c.pv. } \\ \text { vesicatoria }\end{array} \\ 329 & \text { Q3BWY6_XANC5 } & \text { X.c.pv. }\end{array}$

XAC0973 21.8/9.68

$14.0 / 5.9$

$4 / 15 \%$

$+5.1$

$\begin{array}{lll}\text { XAC0957 } & 43.3 / 5.45 \quad 67.0 / 6.2 & 25 / 24 \%\end{array}$

173 Elongation factor Tu

$$
329 \text { Q3BWY6_XANC5 } \begin{array}{ll}
\text { X.c.pv. } \\
\text { vesicatoria }
\end{array}
$$

$\begin{array}{lll}\text { XAC0957 } & 43.3 / 5.45 \quad 48.0 / 5.9 & 20 / 42 \%\end{array}$

$+4.4$

14 Protein fate (folding, modification and destination)

14.01 Protein folding and stabilization

416 Chaperone protein DnaK 
Table 1 Selected proteins differentially expressed during X. a. pv. citri biofilm formation (Continued)

\begin{tabular}{|c|c|c|c|c|c|c|c|c|c|}
\hline \multicolumn{10}{|c|}{20 Cellular transport, transport facilities and transport routes } \\
\hline \multicolumn{10}{|c|}{ 20.03 Transport facilities } \\
\hline 151 & $\begin{array}{l}\text { Regulator of pathogenicity } \\
\text { factors }\end{array}$ & 104 & Q8PJM6_XANAC & X. a.pv. citri & XAC2504 & $41.3 / 5.98$ & 41.0/4.3 & $8 / 21 \%$ & +3.2 \\
\hline 429 & $\begin{array}{l}\text { Regulator of pathogenecity } \\
\text { factors }\end{array}$ & 729 & Q8PJM6_XANAC & X. a.pv. citri & XAC2504 & $41.3 / 5.98$ & 47.0/4.5 & $55 / 61 \%$ & +2.7 \\
\hline 486 & $\begin{array}{l}\text { Regulator of pathogenecity } \\
\text { factors }\end{array}$ & 231 & Q8PJM6_XANAC & X. a.pv. citri & XAC2504 & $41.3 / 5.98$ & $48.0 / 5.2$ & $16 / 30 \%$ & +2.2 \\
\hline 526 & $\begin{array}{l}\text { *Regulator of pathogenecity } \\
\text { factors }\end{array}$ & 183 & Q3BS50_XANC5 & $\begin{array}{l}\text { X.c.pv. } \\
\text { vesicatoria }\end{array}$ & XAC2504 & $46.4 / 7.10$ & 48.0/5.3 & $16 / 21 \%$ & +1.8 \\
\hline 555 & $\begin{array}{l}\text { *Regulator of pathogenecity } \\
\text { factors }\end{array}$ & 148 & Q3BS50_XANC5 & $\begin{array}{l}\text { X.c.pv. } \\
\text { vesicatoria }\end{array}$ & XAC2504 & $46.4 / 7.10$ & $42.0 / 4.9$ & $11 / 12 \%$ & +2.8 \\
\hline \multicolumn{10}{|c|}{30 Cellular communication/Signal transduction mechanism } \\
\hline 103 & OmpA-related protein & 371 & Q8PER6_XANAC & X. a.pv. citri & XAC4274 & $110.1 / 5.29$ & 75.0/5.9 & $28 / 16 \%$ & +2.9 \\
\hline 1 & TonB-dependent receptor & 1406 & Q8PI48_XANAC & X. a.pv. citri & XAC3050 & 105.8/4.76 & 42.0/4.1 & $89 / 34 \%$ & +2.9 \\
\hline 2 & TonB-dependent receptor & 1441 & Q8PI48_XANAC & X. a.pv. citri & XAC3050 & 105.8/4.76 & $58.0 / 6.7$ & $85 / 35 \%$ & +2.9 \\
\hline 74 & TonB-dependent receptor & 597 & Q8PI48_XANAC & X. a.pv. citri & XAC3050 & 105.8/4.76 & 20.0/4.7 & $27 / 15 \%$ & +3.4 \\
\hline 219 & TonB-dependent receptor & 356 & Q8PI48_XANAC & X. a.pv. citri & XAC3050 & 105.8/4.76 & 68.0/6.4 & $23 / 23 \%$ & +2.2 \\
\hline 466 & $\begin{array}{l}\text { TonB-dependent receptor- } \\
\text { precursor }\end{array}$ & 113 & Q8PI27_XANAC & X.a.pv. citri & XAC3071 & $97.3 / 5.14$ & $54.0 / 6.8$ & $7 / 4 \%$ & +3.6 \\
\hline 55 & ${ }^{*}$ TonB-dependent receptor & 166 & Q2HPF0_9XANT & $\begin{array}{l}\text { X.a.pv. } \\
\text { glycines }\end{array}$ & XAC3489 & $88.9 / 4.93$ & $58.0 / 6.4$ & $8 / 9 \%$ & +2.8 \\
\hline 168 & TonB-dependent receptor & 636 & Q8PGX3_XANAC & X. a.pv. citri & XAC3489 & $89.0 / 5.00$ & $55.0 / 6.0$ & $38 / 29 \%$ & +4.9 \\
\hline 38 & *TonB-dependent receptor & 594 & Q8PHT1_XANAC & X.a.pv. citri & XAC3168 & $87.3 / 5.20$ & $48.0 / 6.0$ & $44 / 21 \%$ & -1.8 \\
\hline 15 & TonB-dependent receptor & 229 & Q8PH16_XANAC & X.a.pv. citri & XАC3444 & 103.2/4.79 & $66.0 / 6.4$ & $20 / 14 \%$ & -3.5 \\
\hline \multicolumn{10}{|c|}{ 30.01.05.01 Protein kinase } \\
\hline 49 & Adenylate kinase & 93 & Q3BPM9_XANC5 & $\begin{array}{l}X . c . p v . \\
\text { vesicatoria }\end{array}$ & XAC3437 & $19.9 / 5.33$ & 18.0/5.9 & $8 / 24 \%$ & -2.4 \\
\hline 420 & $\begin{array}{l}\text { Histidine kinase- } 2 \text { component } \\
\text { sensor system }\end{array}$ & 40 & Q3BTZ4_XANC5 & $\begin{array}{l}X . c . p v . \\
\text { vesicatoria }\end{array}$ & XAC1991 & $45.9 / 5.33$ & $48.0 / 5.5$ & $10 / 13 \%$ & -2.2 \\
\hline \multicolumn{10}{|c|}{34 Interaction with the environment } \\
\hline 86 & YapH protein & 51 & Q8PKM0_XANAC & X. a.pv. citri & XAC2151 & $306.9 / 4.15$ & $68.0 / 5.5$ & $1 / 0 \%$ & +4.1 \\
\hline \multicolumn{10}{|c|}{42 Biogenesis of cellular components } \\
\hline \multicolumn{10}{|c|}{ 42.27 Extracellular/secretion protein } \\
\hline 432 & $\begin{array}{l}\text { OmpW family outer memb. } \\
\text { prot. precursor }\end{array}$ & 151 & Q3BP00_XANC5 & $\begin{array}{l}\text { X.c.pv. } \\
\text { vesicatoria }\end{array}$ & XAC3664 & 23.8/4.97 & 17.0/6.1 & $5 / 13 \%$ & +2.2 \\
\hline
\end{tabular}

${ }^{a}$ Gene accession number in $X$. axonopodis pv. citri genome of the identified protein.

${ }^{b}$ Fold change in biofilm compared to planktonic cultures.

* Protein spots 55 and 38 were previously identified as "outer membrane active sucrose transporter" and "ferric enterobactin receptor" are now classified as TonBdependent receptor, while protein spots 526 and 555 were previously identified as "carbohydrate selective porin" and is now classified as Regulator of pathogenecity factors.

The identified differentially expressed proteins were used to determine enriched GO categories in biological processes, molecular function and cellular localization. The main enriched categories for the up- and downregulated proteins with an average fold change of minimum \pm 1.5 are represented graphically (Figure 3 ). The major biological processes and cellular localization categories that changed in the $X . a$. pv. citri biofilms are 'transporter activity' and 'external encapsulating structure', respectively. The categories that showed enrichment in the up-regulated proteins include 'catabolic process', 'external encapsulating structure,' 'receptor activity' and 'transporter activity'; while most of the downregulated proteins were in the categories of 'biosynthetic process', 'nucleobase, nucleoside, nucleotide and nucleic acid metabolic process', 'metabolic process', 'catabolic 


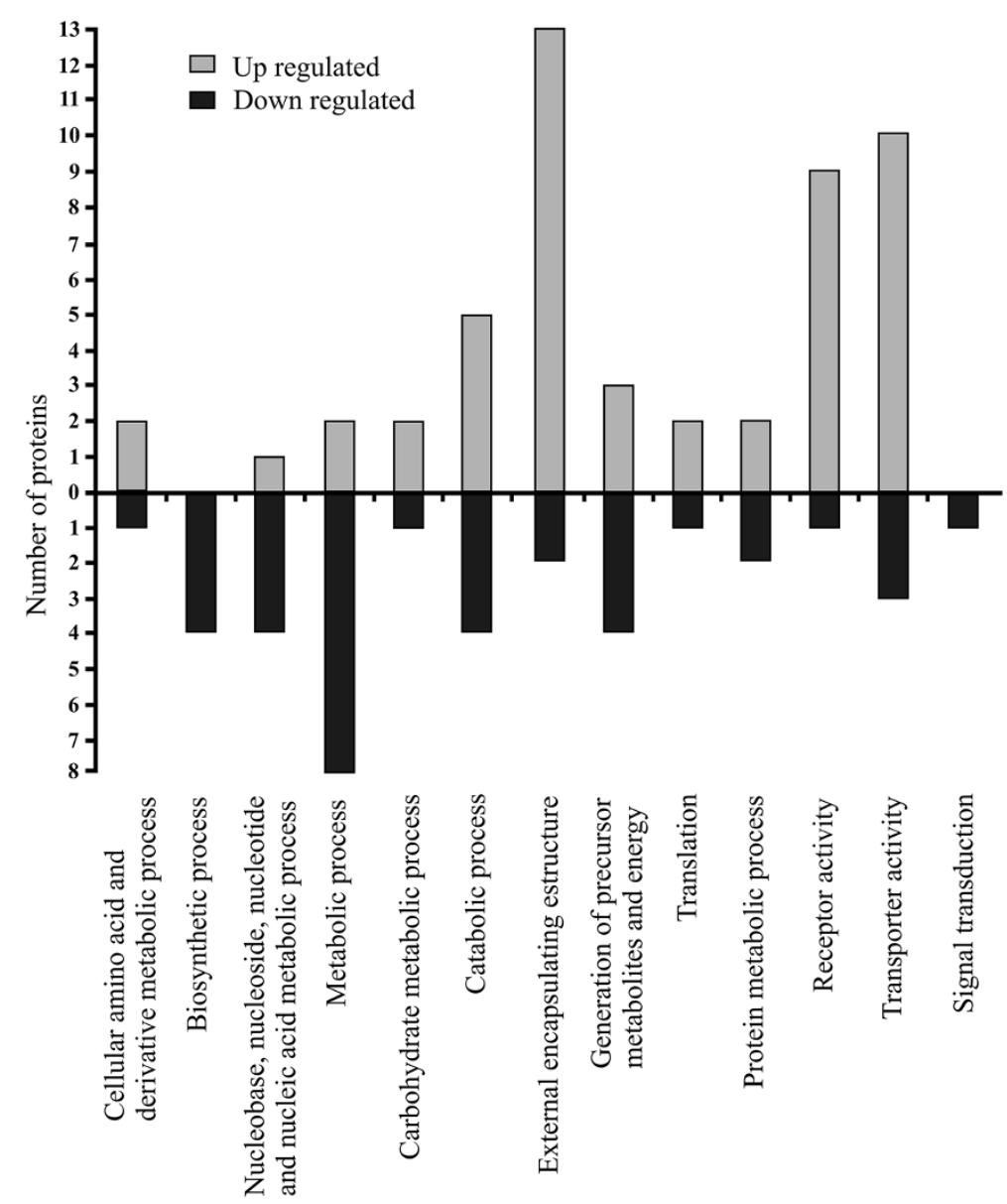

Figure 3 Gene ontology (GO) terms enriched in the identified up- and down-regulated proteins in $X . a$. pv. citri biofilms compared to planktonic cultures. Proteins were considered differentially expressed in X. a. pv. citri biofilms when variation was a minimum of 1.5-fold $(p<0.05)$. The $\mathrm{GO}$ enrichment analysis was performed using Blast2GO.

process' and 'generation of precursor metabolites and energy'.

It is noteworthy that among the identified proteins, some have previously been shown to be involved in biofilm formation or regulation in other pathogenic bacteria. These include a the non-fimbrial adhesin, YapH [26], the FadL porin [27], citrate synthase [28], UDPglucose dehydrogenase [19], the molecular chaperone DnaK [29-31], the elongation factor Ef-Tu [29,32], the polynucleotide phosphorylase [33] and a TonB-dependent receptor protein [19] (Table 2). These findings further validate our experimental results.

Specifically for $X$. a. pv. citri, we observed only a small overlap with recently published data that identified genes involved in biofilm formation by transposon mutagenesis [19]. The common proteins include UDP-glucose dehydrogenase and a TonB-dependent receptor proteins [19]. A possible explanation for this may be that transposon mutagenesis also identifies genes that are indirectly involved in biofilm formation, and additionally many of
Table 2 Differentially expressed proteins detected previously in biofilms

\begin{tabular}{lll}
\hline Protein & Species & Reference \\
\hline $\begin{array}{l}\text { Non-fimbrial adhesion, } \\
\text { YapH }\end{array}$ & X. axonopodis pv. phaseoli & 26 \\
$\begin{array}{l}\text { Outer membrane } \\
\text { protein, FadL }\end{array}$ & P. fluorescens & 27 \\
$\begin{array}{l}\text { Citrate synthase } \\
\begin{array}{l}\text { UDP-glucose } \\
\text { dehydrogenase }\end{array}\end{array}$ & B. cenocepacia & 28 \\
$\begin{array}{l}\text { Molecular chaperone } \\
\text { DnaK }\end{array}$ & X. axonopodis pv. citri & 19 \\
$\begin{array}{l}\text { Elongation factor } \\
\text { Ef-Tu }\end{array}$ & P. intermedia & $29,30,31$ \\
$\begin{array}{l}\text { Polynucleotide } \\
\text { phosphorylase }\end{array}$ & S. pneumoniae, X. fastidiosa & 29,32 \\
$\begin{array}{l}\text { TonB-dependent } \\
\text { receptor }\end{array}$ & X. coli & 33 \\
\hline
\end{tabular}


the identified genes may be required for the first stages of biofilm formation, such as adherence to the surface. Here, we focused on the proteins present in mature biofilms and for this reason many of the genes found in the genomewide scale assay may be not differently expressed in this structure.

The most enriched categories for the up-regulated proteins in $X$. a. pv. citri biofilm are 'external encapsulating structure', 'transporter activity' and 'receptor activity', and include the outer membrane receptors termed TonB-dependent receptors (TBDRs). Among them, the OmpA-related protein (XAC4274, spot 103) and TonBdependent receptors (XAC3050, spots 1, 2, 74, 219; XAC3071, spot 466 and XAC3489, spots 55 and 168) were up-regulated, while the TonB-dependent receptors (XAC3168, spot 38 and XAC3444, spot 15) were downregulated in $X . a$. pv. citri biofilms. The TBDR proteins are localized in the outer membrane of gram-negative bacteria and their most prominent recognized role is the transport of iron-siderophore complexes and cobalamin into the periplasm [34]. Transport via TBDRs is an active process requiring energy that is provided by the inner membrane TonB-ExbB-ExbD protein complex [35]. Generally, expression of the genes encoding for these receptors is activated under conditions of iron starvation and repressed in the presence of iron by the ferric-uptake regulator (Fur) repressor [36]. Several genome sequences of gram-negative bacteria were examined to determine the number of TBDRs present in each genome, and it was demonstrated that only a number of these bacteria, among them the Xanthomonas species, have an over-representation of TBDRs [37]. Most of the analyzed bacteria with an elevated number of TBDRs share the ability to metabolize complex carbohydrates. Therefore, it was postulated that some Xanthomonas TBDRs might be involved in the transport of plantderived molecules [37], and this hypothesis was confirmed with the characterization of two TBDRs from Xanthomonas campestris pv. campestris and Caulobacter crescentus, that transport sucrose and maltodextrins, respectively $[37,38]$. It was also suggested that other TBDRs might be involved in signal transduction processes [39]. Our proteomics results suggest that TBDRs participates in $X$. a. pv. citri biofilm formation and probably has a role in the adaptation to this lifestyle by modulating carbohydrate transport and utilization or signal perception and/or transduction. This hypothesis is supported by a recent study in $X . a$. pv. citri that showed that a transposon insertion mutant in a different TBDR (XAC0144) resulted in impaired in biofilm formation [19].

Other proteins that were up-regulated in biofilms and belonging to the categories 'transporter activity' and 'receptor activity' processes were identified as outer membrane proteins (OMPs) or porins. Porins are integral membrane $\beta$-barrel proteins and act as a selective barrier enabling the passage of nutrients, waste products, water and chemical signals through formed pores [40]. Within the class of porins, FadL (XAC0019, spot 609), a protein that allows the passage of fatty acids [41], was up-regulated in $X$. a. pv. citri biofilms, and was previously observed as important for bacterial virulence [14]. In Pseudomonas fluorescens, FadL has been reported in biofilms on abiotic surfaces, and it has been suggested that the long chain of fatty acids bound to FadL alter surface hydrophobicity and therefore adhesion characteristics [27]. Interestingly, the outer membrane porin termed "Regulator of pathogenicity factors" (RpfN) in the $X$. a. pv. citri genome (XAC2504, spots 151, 429, $486,526,555)$ was also up-regulated in the biofilms. This particular porin is encoded in a genomic region along with genes specialized in internalization of fructose and was suggested to play a role in carbohydrate transport [42], that in turn may be necessary for $X$. $a$. pv. citri adaptation to biofilm lifestyle. Moreover, the Burkholderia pseudomallei homolog to RpfN, named OprB, was shown to be important for optimal biofilm formation [43]. The OmpW (XAC3664; spot 432) was another up-regulated porin in $X$. $a$. pv. citri biofilms. It is involved in the transport of small hydrophilic molecules across the bacterial outer membrane [44]. Recent studies in Salmonella typhimurium suggest that this porin may have a role in the protection of bacteria against various forms of environmental stress by operating as efflux channel for toxic compounds [45]. We therefore hypothesize that OmpW may be involved in protecting $X$. a. pv. citri biofilms.

UDP-glucose dehydrogenase (UGD) (XAC3581, spot 220) was over-expressed in $X$. a. pv. citri biofilms (Table 1) and enriched in the category 'metabolic process'. This enzyme catalyzes the conversion of UDPglucose to UDP-glucuronic acid and the cellular functions of UGD have been investigated in a number of organisms establishing a role in detoxification, polysaccharide biosynthesis as well as embryonic development [46]. Moreover, a double mutant in Pseudomonas aeruginosa UGD (PA2022-PA3559) produced thinner biofilms than the wild type PAO1 and it has been suggested that the functional role of UGD in $P$. aeruginosa, involves hyaluronic acid (polysaccharide consisting of alternative GlcUA and GlcNAc residues) synthesis, which also contributes to biofilm formation [47]. In X. campestris pv. campestris, UGD is required for the biosynthesis of xanthan gum that is a component of the exopolysaccharide (EPS). Therefore, together with the well established role of $X$. a. pv. citri EPS in bacterial adherence and biofilm formation [10,11,19], the over-expression of UGD in $X$. a. pv. citri biofilms is consistent with a major role of EPS under biofilm growth conditions. Also consistent with this conclusion is the 
absence of biofilm formation in a X. a. pv. citri UGD deletion mutant [19].

The non-fimbrial adhesin, YapH (XAC2151, spot 86), a protein up-regulated in $X$. a. pv. citri biofilms, is an adhesin that belongs to the family of the filamentous hemagglutinins secreted by the two-partner secretion system [48]. In $X$. axonopodis pv. phaseoli, a YapH ortholog was discovered to be involved in the adhesion process to biotic and abiotic surfaces and also in biofilm formation [26]. We previously characterized another filamentous hemagglutinin named $X . a$. pv. citri FhaB, and showed that it is critical for $X$. $a$. pv. citri biofilm formation [6]. In agreement with these studies, the present results substantiate the role of this family of adhesins in $X$. a. pv. citri biofilm formation.

Among the category 'nucleic acid metabolic process', the polynucleotide phosphorylase (PNPase) (XAC2683, spot 153) was down-regulated in biofilms. PNPase is an important enzyme involved in RNA processing and turnover [49]. Recently, it was demonstrated that PNPase negatively regulates cell aggregation and biofilm formation in E. coli by inhibiting the expression of genes involved in the production of the EPS poly- $N$-acetylglucosamine at post-transcriptional level [33]. In this context, our results may suggest that in $X . a$. pv. citri, this enzyme also enables the adaptation to the biofilm lifestyle.

Several proteins involved in other categories such as protein synthesis, folding and stabilization were upregulated in $X$. a. pv. citri biofilm, including the Elongation factor $\mathrm{Tu}$ (Ef-Tu) (XAC0957, spots 26, 173), the 50s ribosomal protein L4 (XAC0973; spot 79) and the molecular chaperone DnaK (XAC1522, spot 416). Our results are in agreement with reports which described an increase in $30 \mathrm{~S}$ ribosomal protein $\mathrm{S} 1, \mathrm{Ef}-\mathrm{Tu}, 50$ s ribosomal protein L1, and DnaK during biofilm formation in Streptococcus pneumoniae [29]. Similarly, Pseudomonas aeruginosa biofilms display an up-regulation of ribosome recycling factor and $50 \mathrm{~S}$ ribosomal protein [50]. The increase in Ef-Tu and the 50s ribosomal protein L4 observed in $X$. a. pv. citri biofilm may be related to participation in protein synthesis and folding and this in turn may be a specific requirements of the lifestyle. However, for Ef-Tu, other functions such as participation in bacterial aggregation also need to be considered since this factor has also been identified as a cell wall associated component in several bacterial species where it mediates the binding to host proteins (e.g. to human plasminogen in Listeria monocytogenes) [51] and in Mycoplasma pneumoniae where it directly binds fibronectin, suggesting a role of Ef-Tu in aggregation [52]. Ef$\mathrm{Tu}$ was also over-expressed in the wild type strain of Lactobacillus crispatus as compared to an isogenic mutant that lost the aggregative phenotype and strengthening the claim for a role in adhesion [53]. Moreover, in the citrus pathogen Xylella fastidiosa, Ef-Tu was reported to be up-regulated in biofilms [32]. Recent work demonstrated that in $X$. a. pv. citri, DnaK is necessary for the bacteria to achieve full virulence [14]. Several proteomics reports associate the up-regulation of DnaK to biofilm formation. Among them, a dnaK knock-down mutant of Streptococcus mutans with reduced levels of DnaK $(<95 \%)$ shows impaired biofilm-forming capacity [30], while DnaK expression was up-regulated in a Prevotella intermedia biofilm-forming strain when compared to a variant lacking biofilm formation [31].

Several proteins that were enriched in the categories 'metabolic process', 'generation of precursor metabolites and energy', 'catabolic process' and 'biosynthetic process' showed altered expression patterns in $X$. a. pv. citri biofilms. A number of enzymes of the tricarboxylic acid (TCA) cycle were also detected as differentially expressed in the biofilm compared to planktonic cultures. Since the TCA cycle plays a central role in metabolism, our finding indicates that the two lifestyles may have markedly different metabolic and energy requirements. The three differentially expressed enzymes of the TCA cycle are citrate synthase (XAC3388, spot 235), malate dehydrogenase (XAC1006, spot 98) and dihydrolipoamide S-succinyltransferase (XAC1534, spot 121). Citrate synthase catalyzes the first reaction in the TCA cycle converting oxaloacetate and acetyl-coenzyme A into citrate and coenzyme A $(\mathrm{CoA})$. Incidentally, it has been observed that a citrate synthase of Burkholderia cenocepacia is necessary for optimum levels of biofilm formation and virulence [28]. In Geobacter sulfurreducens, uniform expression of citrate synthase genes was noted throughout biofilms [54]. The second over-expressed protein in biofilms was identified as malate dehydrogenase, the enzyme that catalyzes the reversible conversion of L-malate to oxaloacetate, and the synthesis of this enzyme is influenced by cell growth conditions such as oxygenation and the nature of carbon substrates [55]. Succinate dehydrogenase (spot 591) was down-regulated in the biofilm. Succinate dehydrogenase complex catalyzes the oxidation of succinate to fumarate, donating $\mathrm{FADH}_{2}$ for oxidative phosphorylation. In the presence of oxygen, the TCA cycle operates as an oxidative pathway coupled to aerobic respiration. Under oxygen-limiting conditions, the TCA cycle operates as reductive (incomplete) pathway dedicated largely to the synthesis of precursors blocking the steps from $\alpha$-ketoglutarate to succinyl-CoA. In the reductive pathway, succinyl-CoA is synthesized using the enzyme fumarate reductase as an alternative to succinate dehydrogenase, leading to the down-regulation of succinate dehydrogenase [56]. Given the down-regulation of succinate dehydrogenase in $X . a$. pv. citri biofilms, our results might suggest that in biofilms, the TCA cycle is converted into the reductive pathway possibly because of oxygen 
limitations under these growth conditions. Accordingly, succinate dehydrogenase is directly linked to the respiratory chain and in $E$. coli, an increase in oxygen respiration correlated with succinate dehydrogenase over-expression [57]. Moreover, X. a. pv. citri biofilms showed a down-regulation of protein involved in energy generation, such as ATP-synthase (XAC3649, spot 76), phosphoglycerate kinase (XAC3347, spot 442) and NADH-ubiquinone oxidoreductase (XAC2699, spot 422). Phosphoglycerate kinase enzyme is involved in later reactions of the glycolytic pathway; therefore its inhibition should lead to an increased pool of glycolytic intermediates in the early steps that might benefit biosynthetic processes. Furthermore, an enzyme involved in cellular energy homeostasis, adenylate kinase (XAC3437, spot 49) was also down-regulated in X. a. pv. citri biofilms. This enzyme catalyzes the interconversion of adenine nucleotides generating ATP and AMP, a metabolic signaling molecule.

Several antioxidant enzymes enriched in the 'metabolic process' are involved in secondary metabolism. In bacteria, the normal course of aerobic metabolism produces reactive oxygen species (ROS) with the concomitant requirement for the constitutive expression of ROS scavenging systems such as antioxidant enzymes [58]. In accordance with our hypothesis that $X$. a. pv. citri biofilms have a reduced aerobic respiration rate, these biofilms showed a down-regulation in antioxidant enzymes like a $\mathrm{NAD}(\mathrm{PH})$ nitroreductase (XAC0554, spot 60), a short chain dehydrogenase (XAC1484, spot 434) and an aerobic coproporphyinogen-III oxidase (XAC4109, spot 533). Nitroreductases are a family of evolutionarily related proteins involved in the reduction of nitrogencontaining compounds and the short-chain dehydrogenases/reductases represent a large family of enzymes, most of which are NAD- or NADP-dependent oxidoreductases [59]. Coproporphyrinogen III oxidase is encoded by the hemF gene that is involved in heme-biosynthesis [60]. This protein was shown to be a member of the hydrogen peroxide (oxidative stress)-induced regulon responsible for protecting cells from oxidative damage [61]. The 4-hydroxy-2-oxoglutarate (KHG)/phospho-2-dehydro3-deoxygluconate (KDPG) aldolases (XAC2067, spot 331), a key enzyme for the Entner-Doudoroff pathway, was down-regulated in biofilms. The KHG aldolase catalyzes the interconversion of 4-hydroxy-2-oxoglutarate into pyruvate and glyoxylate in the glyoxylate cycle, while KDPG-aldolase induces the interconversion of 6-phospho2-dehydro-3-deoxy-D-gluconate into pyruvate and glyceraldehyde 3-phosphate and the two enzymes are structurally and functionally related [62]. One primary function of the glyoxylate cycle is to replenish the tricarboxylic and dicarboxylic acid intermediates that are normally provided by the TCA cycle. In $X . a$. pv. citri biofilms, several enzymes of the TCA cycle are up-regulated suggesting a reduced requirement for the glyoxylate cycle under this static growth condition.

One GO category ('signal transduction') is enriched in down-regulated proteins only and comprises a putative two-component system sensor histidine kinase underexpressed in X. a. pv. citri biofilms (XAC1991, spot 420). Previously, it was shown that a $X$. $a$. pv. citri mutant that has a transposon insertion at the intergenic region between XAC1990 and XAC1991 induces milder infection symptoms than the wild type strain [14]. Since these genes have the same genomic orientation, this mutation probably impairs only XAC1991 expression. These data may suggest that besides its involvement in $X$. $a$. pv. citri pathogenicity, this sensor histidine kinase may also be involved in the adaptation to different lifestyles.

\section{Transcriptional analysis of selected genes encoding differentially expressed proteins}

We selected some of these genes for further validation by quantitative real-time PCR (qRT-PCR). Total RNA was extracted from $X$. a. pv. citri mature biofilms and from planktonic cells, both grown as for the proteomic study. Bacterial cDNA was obtained from $1 \mu \mathrm{g}$ of total RNA in both growth conditions. The assay was performed with specific primers for the following $X . a$. pv. citri genes: XAC3581 (UDP-glucose dehydrogenase), XAC0973 (50S ribosomal protein L4), XAC0957 (EfTu), XAC2504 (RpfN), XAC3489 (TonB-dependent receptor), XAC2151 (YapH), $\mathrm{XAC} 3664(\mathrm{OmpW})$ and XAC1522 (DnaK). We noted that the changes in transcript levels of theses genes mirrored the changes observed in the proteomics analysis $(\mathrm{p}<0.05)$ (Figure 4).

\section{Conclusions}

Several lines of evidence indicate that $X . a$. pv. citri biofilm formation plays an important part in bacterial pathogenicity. Among them, studies on a variety of impaired biofilm forming mutants have revealed the importance of this lifestyle for the citrus pathogen. Here we identified proteins differentially expressed in a mature $X$. a. pv. citri biofilm as compared to free planktonic cultured cells. A larger number of differentially expressed proteins are down-regulated and relate to metabolic processes suggesting a reduction in energy requirements. Further experiments will show to which extent this is due to reduced metabolic activity at this growth stage. It is also noteworthy, firstly, that proteins that are down-regulated in $X . a$. pv. citri biofilms are enriched for the GO terms 'generation of precursor metabolites and energy' and secondly, that the biofilm proteome mainly displayed changes in outer membrane and receptor or transport proteins suggesting that they may have a role in maintaining a functional external structure as well as 


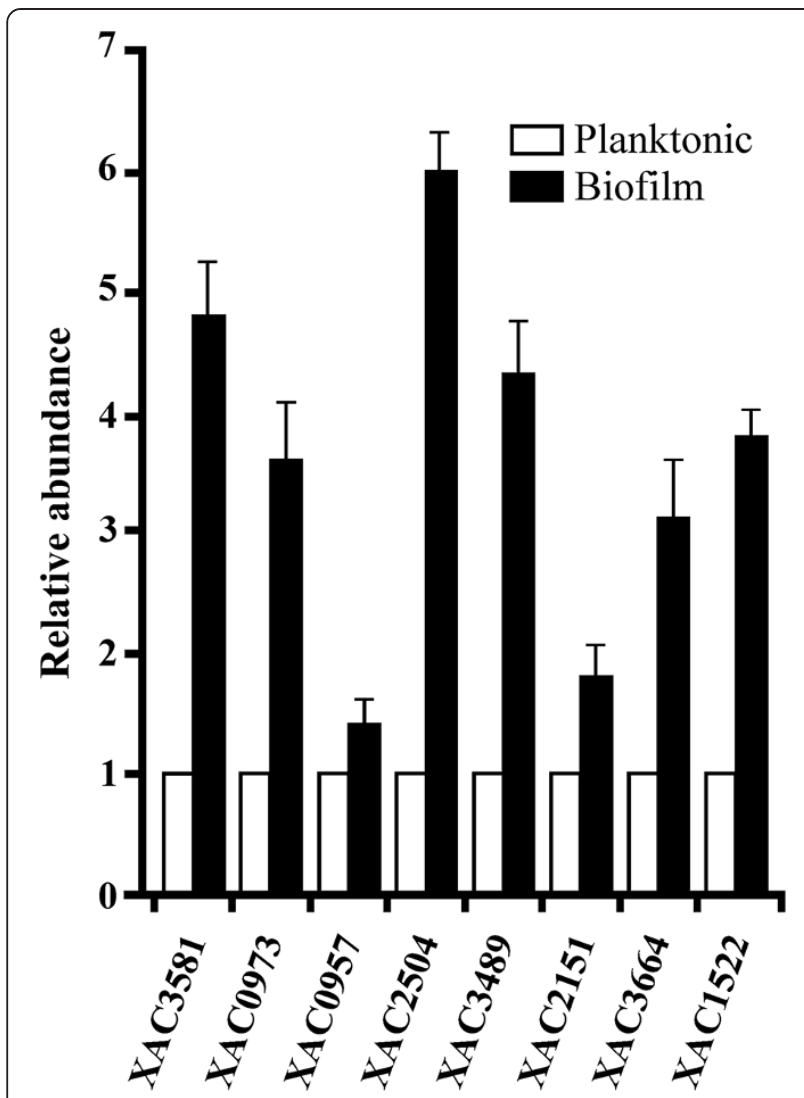

Figure 4 Analysis of the expression of selected genes encoding differentially expressed proteins. A significant difference in expression was detected by qRT-PCR between planktonic and biofilm conditions for selected genes confirming their expression during X. a. pv. citri biofilm formation. Black bars indicate the expression levels of $X . a$. pv. citri transcripts in biofilm compared to a reference planktonic growth (white bars). As a reference gene, a fragment of $16 \mathrm{~S}$ rRNA was amplified. Values represent the means of four independent experiments. Error bars indicate standard deviations. Data were statistically analyzed using one-way ANOVA $(p<0.05)$ and Student $t$-test $(p<0.05)$.

enabling appropriate flow of molecules and signals required in this lifestyle. This study is the first report of a $X . a$. pv. citri biofilm proteome and the information gained will support future comparative analyses of differentially expressed genes and/or proteins involved in biofilm formation. In addition, the data will also inform approaches to a more detailed physiological investigation into the function of individual proteins and their role in biofilm formation.

\section{Methods}

Bacterial strains, culture conditions and media

$X$. axonopodis pv. citri was grown at $28^{\circ} \mathrm{C}$ in Silva Buddenhagen (SB) medium (5 g/l sucrose, 5 g/lyeast extract, $5 \mathrm{~g} / \mathrm{l}$ peptone, and $1 \mathrm{~g} / \mathrm{l}$ glutamic acid, $\mathrm{pH}$ 7.0) and XVM2 medium (20 mM NaCl, $10 \mathrm{mM}\left(\mathrm{NH}_{4}\right)_{2} \mathrm{SO}_{4}$, $1 \mathrm{mM} \mathrm{CaCl}_{2}, 0.01 \mathrm{mM} \mathrm{FeSO}_{4}, 5 \mathrm{mM} \mathrm{MgSO}, 0.16 \mathrm{mM}$
$\mathrm{KH}_{2} \mathrm{PO}_{4}, 0.32 \mathrm{mM} \mathrm{K} \mathrm{KPO}_{4}, 10 \mathrm{mM}$ fructose, $10 \mathrm{mM}$ sucrose and $0.03 \%(\mathrm{w} / \mathrm{v})$ casein acid hydrolysate (casaminoacid), $\mathrm{pH}$ 6.7). Bacteria were grown in SB with shaking until exponential growth phase and then diluted 1:10 in fresh XVM2 medium. For planktonic cultures these dilutions were grown under agitation at $200 \mathrm{rpm}$ on a rotating shaker and cells were recovered after 24 hours of growth at early stationary phase. For biofilms, $2 \mathrm{ml}-$ aliquot of these dilutions were placed in 24-well PVC plates and incubated statically for seven days at $28^{\circ} \mathrm{C}$. In both cases the population size was estimated by recovering bacteria by centrifugation and plating adequate dilutions on SB plates. After 48 hours colonies were counted and related to the volume of the original cultures. The $X$. axonopodis pv. citri strain used in this work is named Xcc99-1330 and was kindly provided by Blanca I. Canteros (INTA Bella Vista, Argentina).

\section{Confocal analysis of biofilm architecture}

The GFP-expressing $X$. a. pv. citri strain previously constructed using the parental strain Xcc99-1330 [6] was used in the present study and statically grown in 24-well PVC plates, as described above, and biofilm development was analyzed at 1, 3 and 7 days by confocal laser scanning microscopy (Nikon Eclipse TE-2000-E2).

\section{Protein extraction and resolubilization for the proteomic analysis}

Cellular pellets of $X . a$. pv. citri planktonic and biofilm cultures were obtained by centrifugation and resuspended in urea buffer ( $9 \mathrm{M}$ urea, $2 \mathrm{M}$ thiourea and $4 \%(\mathrm{w} / \mathrm{v}) 3$ 3-[(3cholamidopropyl)dimethylammonio]-1-propanesulfonate (CHAPS)) with vigorous vortexing at room temperature. Concentration of total protein extracts was estimated by Bradford assay using the Quick Start Bradford protein assay (Bio-Rad). Protein extracts were prepared from three different flasks for both growth conditions.

\section{CyDye labeling}

Prior to 2D-PAGE, protein samples were labeled using the fluorescent cyanine three-dye strategy (CyDyes; GE Healthcare, Sweden), according to manufacturer's instructions. Briefly, proteins $(50 \mu \mathrm{g})$ of an internal standard containing an equal amount of the control and treated samples were incubated with $400 \mathrm{pmol}$ of Cy2, freshly dissolved in dimethyl formamide (DMF), while $X$. $a$. pv. citri planktonic and X. a. pv. citri forming biofilm samples were labeled with $\mathrm{Cy} 3$ and $\mathrm{Cy} 5$, respectively. Dye swap between samples was carried out to avoid artifacts due to preferential labeling. Three biological replicates and two technical replicates were carried out, giving rise to a total of six gel images per growth conditions. All reactions were carried out on ice and in the dark to limit signal quenching. Labeling was performed 
for $30 \mathrm{~min}$ and terminated by incubation with $10 \mathrm{nmol}$ lysine for $10 \mathrm{~min}$. Equal volumes of urea lysis buffer containing $20 \mathrm{mg} / \mathrm{ml}$ DTT and 2\% (v/v) IPG buffer, $\mathrm{pH}$ range 4-7 (GE Healthcare) were added to each sample and incubated for $15 \mathrm{~min}$. After pooling the samples, the volume was adjusted to $125 \mu \mathrm{l}$ with rehydration buffer (7 M urea, $2 \mathrm{M}$ thiourea, 4\% (w/v) CHAPS, $2 \mathrm{mg} / \mathrm{ml}$ DTT and 1\% (v/v) IPG buffer pH 4-7, GE Healthcare) and separated by 2D-DIGE.

\section{Protein separation and quantification by 2D-DIGE electrophoresis}

Labeled protein samples in urea lysis buffer were used to rehydrate $7 \mathrm{~cm}$-long linear IPG strips, $\mathrm{pH}$ range 4-7 (GE Healthcare). Following overnight rehydration at room temperature, strips were focused for a total of 8,750 Vhrs $50 \mu \mathrm{A}$ at $20^{\circ} \mathrm{C}$, as follows: step, $500 \mathrm{~V}$ for 250 Vhrs; step, 1,000 V for 500 Vhrs and step, 8,000 V for 8,000 Vhrs. Prior to SDS-PAGE, strips were equilibrated twice for $15 \mathrm{~min}$ in equilibration buffer (50 mM Tris, $\mathrm{pH} 8.8,30 \%(\mathrm{v} / \mathrm{v})$ glycerol, $6 \mathrm{M}$ urea, 2\% (w/v) SDS) first containing $1 \%(\mathrm{w} / \mathrm{v})$ DTT and then $2.5 \%(\mathrm{w} / \mathrm{v})$ iodoacetamide with gentle shaking. Strips were loaded on top of $12 \%$ SDS-PAGE. Strips were sealed on top of the gel with $1 \%(\mathrm{w} / \mathrm{v})$ agarose in SDS running buffer (25 mM Tris, $192 \mathrm{mM}$ glycine, 0.1\% (w/v) SDS). Gels were run at $50 \mathrm{~V}$ for the first $15 \mathrm{~min}$ and then at $100 \mathrm{~V}$ until the dye reached the bottom of the gels.

\section{Comparative analysis and protein identification}

Gel images were obtained using the Typhoon ${ }^{\mathrm{TM}} 9410$ scanner (GE Healthcare). Cy2-labeled pool samples were imaged using a $488 \mathrm{~nm}$ blue laser and a $520 \mathrm{~nm}$ bandpass (BP) 40 emission filter. Cy3 images were obtained using a $532 \mathrm{~nm}$ green laser and a $520 \mathrm{~nm}$ BP30 emission filter, and the Cy5 images using a $633 \mathrm{~nm}$ red laser and a $670 \mathrm{~nm}$ BP30 emission filter. Images were analyzed with the Delta2D (Decodon, Greifswald, Germany) software. Spot quantities were calculated by summing pixel intensities within the spot boundaries and used for analyzing gene expression. Normalized expression profile data were used to statistically assess changes in protein spot expression. Differentially expressed protein spots between the two groups were calculated using the Student-T test with a critical p-value $\leq 0.05$ and the permutation-based method to avoid biased results that may arise within replicate gels if spot quantities are not normally distributed. The adjusted Bonferroni correction was applied for false discovery rate (FDR) to control the proportion of false positives in the result set. Principal component analysis was performed to determine samples/spots that contributed most to the variance and their relatedness.
Differentially expressed protein spots of interest were manually excised and each placed into separate microcentrifuge tubes. Gel pieces were rinsed briefly with $100 \mu \mathrm{l}$ of $25 \mathrm{mM} \mathrm{NH}_{4} \mathrm{HCO}_{3}$, incubated in $100 \mu \mathrm{l}$ of $25 \mathrm{mM}$ $\mathrm{NH}_{4} \mathrm{HCO}_{3}$ in $50 \%(\mathrm{v} / \mathrm{v})$ acetonitrile $(\mathrm{ACN})$ for $30 \mathrm{~min}$ with gentle shaking, dehydrated with $100 \mu \mathrm{l}$ of $100 \%$ (v/v) ACN for $10 \mathrm{~min}$ and then rehydrated with $100 \mu \mathrm{l}$ of $25 \mathrm{mM}$ $\mathrm{NH}_{4} \mathrm{HCO}_{3}$ for 30 min with gentle shaking. Gel pieces were dehydrated again with $100 \mu \mathrm{l}$ of $100 \%$ (v/v) ACN for $10 \mathrm{~min}$ and completely evaporated. Proteins were reduced with $50 \mu \mathrm{l}$ of $10 \mathrm{mM}$ DTT in $100 \mathrm{mM} \mathrm{NH}_{4} \mathrm{HCO}_{3}$ at $56^{\circ} \mathrm{C}$ for $45 \mathrm{~min}$ and then alkylated with $50 \mu \mathrm{l}$ of $50 \mathrm{mM}$ iodoacetamide in $100 \mathrm{mM} \mathrm{NH} \mathrm{mCO}_{3}$ for $30 \mathrm{~min}$ at room temperature in the dark. Gel pieces were rinsed with $200 \mu \mathrm{l}$ of $100 \mathrm{mM} \mathrm{NH}_{4} \mathrm{HCO}_{3}$ and then with $200 \mu \mathrm{l}$ of $100 \%(\mathrm{v} / \mathrm{v}) \mathrm{ACN}$ for $10 \mathrm{~min}$ each step. These steps were repeated once more. Gel pieces were completely dehydrated and incubated with $200 \mathrm{ng}$ of trypsin (Worthington Biochemical Corp., Lakewood, NJ) diluted in $50 \mathrm{mM} \mathrm{NH} \mathrm{mCO}_{3}$ overnight at $30^{\circ} \mathrm{C}$. Samples were cooled down to room temperature and incubated with $20 \mu \mathrm{l}$ of $20 \mathrm{mM} \mathrm{NH} \mathrm{HCO}_{3}$ for $10 \mathrm{~min}$. Peptides were extracted twice from the gel pieces with $20 \mu \mathrm{l}$ of $5 \%(\mathrm{v} / \mathrm{v})$ formic acid (FA) in 50\% (v/v) ACN for $10 \mathrm{~min}$ each, collected to separate tubes, evaporated and stored at $-20^{\circ} \mathrm{C}$ prior to mass spectrometry analysis.

Digested peptide mixtures were suspended in $0.1 \%$ $(\mathrm{v} / \mathrm{v})$ formic acid (FA) in 5\% (v/v) ACN, and analyzed with an LTQ Orbitrap mass spectrometer (Thermo Scientific, Bremen, Germany) equipped with an electrospray ion source and coupled to an EASY-nanoLC (Proxeon Biosystems, Odense, Denmark) for nano-LC-MS/MS analyses. A volume of $5 \mu \mathrm{l}$ of the peptide mixture was injected onto a $5 \mu \mathrm{m}, 300 \AA$ A, $50 \mathrm{~mm}$ long $\times 0.3 \mathrm{~mm}$ Magic C18AQ (Michrom, Thermo-Scientific) pre-column and a $3 \mu \mathrm{m}$, $100 \AA, 100 \mathrm{~mm}$ long $\times 0.1 \mathrm{~mm}$ Magic C18AQ (Michrom, Thermo-Scientific) column. A spray voltage of $1,500 \mathrm{~V}$ was applied. The mobile phases consisted of $0.1 \%$ FA and $5 \% \mathrm{ACN}(\mathrm{A})$ and $0.1 \% \mathrm{FA}$ and $90 \% \mathrm{ACN}(\mathrm{B})$. A three step gradient of $0-40 \% \mathrm{~B}$ in $20 \mathrm{~min}$, then $40-90 \% \mathrm{~B}$ in $5 \mathrm{~min}$ and finally $90 \%$ B for $20 \mathrm{~min}$ with a flow of $500 \mathrm{nl} / \mathrm{min}$ over $45 \mathrm{~min}$ was applied for peptide elution. The MS scan range was $\mathrm{m} / \mathrm{z} 350$ to 1,600 . The top 10 precursor ions were selected in the MS scan by Orbitrap with resolution $r=60,000$ for fragmentation in the linear ion trap using collision-induced dissociation. The normalized collisioninduced dissociation was set to 35.0.

All spectra were converted to mgf using Proteome Discover version 1.2 (Thermo-Scientific) and submitted to a local MASCOT (Matrix Science, London, UK) server and searched against bacteria in the SwissProt (release 57.15) and MSDB databases (release 9.0) with a precursor mass tolerance of $10 \mathrm{ppm}$, a fragment ion mass tolerance of $0.6 \mathrm{Da}$ and strict trypsin specificity 
allowing up to one missed cleavage, carbamidomethyl as fixed modification and oxidation of methionine residues as variable modification. Proteins were considered positive if the MASCOT score was over the $95 \%$ confidence limit corresponding to a score $>35$ for proteobacteria.

\section{RNA preparation and quantitative real-time PCR (qRT-PCR)}

Total RNA from $X$. a. pv. citri mature biofilms and planktonic cells was extracted using TRIzol ${ }^{\circ}$ reagent (Invitrogen), according to the manufacturer's instructions. After DNAse (Promega) treatment, cDNA was synthesized from $1 \mu \mathrm{g}$ of total RNA using M-MLV RT (Promega) and the oligonucleotide dN6 was added as follows: $200 \mathrm{U}$ of M-MLV RT (Promega, USA), $0.25 \mu \mathrm{g}$ of primer $\mathrm{dN6}$ and $0.5 \mathrm{mM}$ of deoxynucleoside triphosphates (dNTPs) (reaction final volume: $20 \mu \mathrm{l}$ ) and incubated for $1 \mathrm{~h}$ at $42^{\circ} \mathrm{C}$, and then for 10 min at $94^{\circ} \mathrm{C}$. The qRT-PCRs were performed by combining $1 \mu \mathrm{l}$ of cDNA template, $0.5 \mathrm{U}$ of Go Taq DNA polymerase (Promega), $1 \times$ reaction buffer, $0.2 \mathrm{mM}$ dNTPs and $20 \mathrm{pmol}$ of each primer (final reaction volume, $20 \mu \mathrm{l}$ ) in a Mastercycler ep realplex thermal cycler (Eppendorf) using SYBR Green I (Roche) to monitor double-stranded DNA (dsDNA) synthesis. The qRT-PCR conditions were set to $95^{\circ} \mathrm{C}$ for $1 \mathrm{~min}$, followed by 40 cycles of $95^{\circ} \mathrm{C}$ for $15 \mathrm{~s}, 55^{\circ} \mathrm{C}$ for $30 \mathrm{~s}$ and $72^{\circ} \mathrm{C}$ for $40 \mathrm{~s}$. The primer pairs used for qRT-PCR are provided in Additional file 2: Table S2. As a reference gene, a fragment of $16 \mathrm{~S}$ rRNA was amplified using the same qRT-PCR conditions. Values were normalized by the internal reference $\left(\mathrm{Ct}_{\mathrm{r}}\right)$ according to the equation $\Delta \mathrm{Ct}=\mathrm{Ct}-\mathrm{Ct}_{\mathrm{r}}$, and quantified as $2^{-\Delta \mathrm{Ct}}$. A second normalization using a control (time $=0$ days) $\left(\mathrm{Ct}_{\mathrm{c}}\right), \Delta \Delta \mathrm{Ct}=\mathrm{Ct}-\mathrm{Ct}_{\mathrm{c}}$, produces a relative quantification: $2^{-\Delta \Delta C t}$ [63]. Values are the means of four independent experiments. Results were analyzed using one-way ANOVA $(\mathrm{p}<0.05)$ and Student $t$-test $(\mathrm{p}<0.05)$.

\section{GO enrichment analysis}

Proteins were considered as differentially expressed when variations between planktonic and biofilm grown cells were at least 1.5 -fold and the quantitation p-value of 0.05 . The GO enrichment analysis was performed using Blast2GO [64-66].

\section{Additional files}

Additional file 1: Table S1. Complete list of the differentially expressed proteins during $X$. a. pv. citri biofilm formation.

Additional file 2: Table S2. Oligonucleotides used in GRT-PCR of selected genes.

\section{Competing interests}

The authors declare that they have no competing interests.

\section{Authors' contributions}

TZ, JO and NG conceived the project and designed the experiments. TZ, LT, CM and BSG designed and performed the experiments. All authors contributed to the analysis and interpretation of the data and LT, CM, BSG, CG, JO and NG wrote the manuscript. All authors read and approved the manuscript.

\section{Acknowledgements}

We thank Rodrigo Vena for assistance with the confocal microscopy facility and Microquin for the culture media, and the Proteomics laboratory from the Biosciences core laboratories, King Abdullah University of Science and Technology, for providing the facility and equipment for gel electrophoresis and mass spectrometry analyses. This work was supported by PICT2010-1507 and PICT2010-0300 from Agencia Nacional de Promoción Científica y Tecnológica and PIP2010-2012from Consejo Nacional de Investigaciones Científicas y Tecnológicas (CONICET), Argentina.

\section{Author details}

${ }^{1}$ Instituto de Biología Molecular y Celular de Rosario, Consejo Nacional de Investigaciones Científicas y Técnicas (IBR-CONICET), Ocampo y Esmeralda, Rosario, Santa Fe, Argentina. ${ }^{2}$ Division of Biological and Environmental Sciences and Engineering, King Abdullah University of Science and Technology, Thuwal23955-6900, Saudi Arabia.

Received: 20 March 2013 Accepted: 2 August 2013

Published: 7 August 2013

\section{References}

1. da Silva AC, Ferro JA, Reinach FC, Farah CS, Furlan LR, Quaggio RB, Monteiro-Vitorello CB, Van Sluys MA, Almeida NF, Alves LM, et al: Comparison of the genomes of two Xanthomonas pathogens with differing host specificities. Nature 2002, 417(6887):459-463.

2. Graham JH, Gottwald TR, Cubero J, Achor DS: Xanthomonas axonopodis pv. citri: factors affecting successful eradication of citrus canker. Mol Plant Pathol 2004, 5(1):1-15.

3. Costerton JW, Lewandowski Z, Caldwell DE, Korber DR, Lappin-Scott HM: Microbial biofilms. Annu Rev Microbiol 1995, 49:711-745.

4. Costerton JW, Stewart PS, Greenberg EP: Bacterial biofilms: a common cause of persistent infections. Science 1999, 284(5418):1318-1322.

5. Danhorn T, Fuqua C: Biofilm formation by plant-associated bacteria. Annu Rev Microbiol 2007, 61:401-422.

6. Gottig N, Garavaglia BS, Garofalo CG, Orellano EG, Ottado J: A filamentous hemagglutinin-like protein of Xanthomonas axonopodis pv. citri, the phytopathogen responsible for citrus canker, is involved in bacterial virulence. PLoS One 2009, 4(2):4358.

7. Malamud F, Torres PS, Roeschlin R, Rigano LA, Enrique R, Bonomi HR, Castagnaro AP, Marano MR, Vojnov AA: The Xanthomonas axonopodis pv. citri flagellum is required for mature biofilm and canker development. Microbiology 2011, 157(Pt 3):819-829.

8. Sgro GG, Ficarra FA, Dunger G, Scarpeci TE, Valle EM, Cortadi A, Orellano EG, Gottig N, Ottado J: Contribution of a harpin protein from Xanthomonas axonopodis pv. citri to pathogen virulence. Mol Plant Pathol 2012, 13(9):1047-1059.

9. Dunger $\mathrm{G}$, Relling VM, Tondo ML, Barreras M, lelpi L, Orellano EG, Ottado J: Xanthan is not essential for pathogenicity in citrus canker but contributes to Xanthomonas epiphytic survival. Arch Microbiol 2007, 188(2):127-135.

10. Rigano LA, Siciliano F, Enrique R, Sendin L, Filippone P, Torres PS, Questa J, Dow JM, Castagnaro AP, Vojnov AA, et al: Biofilm formation, epiphytic fitness, and canker development in Xanthomonas axonopodis pv. citri. Mol Plant Microbe Interact 2007, 20(10):1222-1230.

11. Guo Y, Kim JS, Wang N: Requirement of the galU gene for polysaccharide production by and pathogenicity and growth In Planta of Xanthomonas citri subsp. citri. Appl Environ Microbiol 2010, 76(7):2234-2242.

12. Yan $Q$, Hu X, Wang $N$ : The novel virulence-related gene nlxA in the lipopolysaccharide cluster of Xanthomonas citri ssp. citri is involved in the production of lipopolysaccharide and extracellular polysaccharide, motility, biofilm formation and stress resistance. Mol. Plant Pathol 2012, 13(8):923-934 
13. Li J, Wang N: The gpsX gene encoding a glycosyltransferase is important for polysaccharide production and required for full virulence in Xanthomonas citri subsp. citr. BMC Microbiol 2012, 12:31

14. Yan $Q$, Wang N: High-throughput screening and analysis of genes of Xanthomonas citri subsp. citri involved in citrus canker symptom development. Mol Plant Microbe Interact 2012, 25(1):69-84.

15. Li J, Wang N: The wxacO gene of Xanthomonas citri ssp. citri encodes a protein with a role in lipopolysaccharide biosynthesis, biofilm formation, stress tolerance and virulence. Mol Plant Pathol 2011, 12(4):381-396.

16. Petrocelli S, Tondo ML, Daurelio LD, Orellano EG: Modifications of Xanthomonas axonopodis pv. citri lipopolysaccharide affect the basal response and the virulence process during citrus canker. PLoS One 2012(7):40051.

17. Malamud F, Conforte VP, Rigano LA, Castagnaro AP, Marano MR: Morais do Amaral A. HrpM is involved in glucan biosynthesis, biofilm formation and pathogenicity in Xanthomonas citri ssp. citri. Mol Plant Pathol: Vojnov AA; 2012

18. Yan Q, Wang N: The ColR/ColS two-component system plays multiple roles in the pathogenicity of the citrus canker pathogen Xanthomonas citri subsp. citri. J Bacteriol 2011, 193(7):1590-1599.

19. Li J, Wang N: Genome-wide mutagenesis of Xanthomonas axonopodis pv. citri reveals novel genetic determinants and regulation mechanisms of biofilm formation. PLoS One 2011, 6(7):e21804.

20. Karatan E, Watnick P: Signals, regulatory networks, and materials that build and break bacterial biofilms. Microbiol Mol Biol Rev 2009, 73(2):310-347.

21. Wengelnik K, Marie C, Russel M, Bonas U: Expression and localization of HrpA1, a protein of Xanthomonas campestris pv. vesicatoria essential for pathogenicity and induction ofthe hypersensitive reaction. J Bacterio/ 1996, 178(4):1061-1069.

22. Allison DG: The biofilm matrix. Biofouling 2003, 19(2):139-150

23. Deringer JR, Chen C, Samuel JE, Brown WC: Immunoreactive Coxiella burneti Nine Mile proteins separated by 2D electrophoresis and identified by tandem mass spectrometry. Microbiology 2011, 157(Pt 2):526-542.

24. Marondedze C, Thomas LA: Insights into fruit function from the proteome of the hypanthium. J Plant Physiol 2012, 169(1):12-19.

25. Bevan M, Bancroft I, Bent E, Love K, Goodman H, Dean C, Bergkamp R, Dirkse W, Van Staveren M, Stiekema W, et al: Analysis of $1.9 \mathrm{Mb}$ of contiguous sequence from chromosome 4 of Arabidopsis thaliana. Nature 1998, 391(6666):485-488.

26. Darsonval A, Darrasse A, Durand K, Bureau C, Cesbron S, Jacques MA: Adhesion and fitness in the bean phyllosphere and transmission to seed of Xanthomonas fuscans subsp. fuscans. Mol Plant Microbe Interact 2009, 22(6):747-757

27. De Lima Pimenta A, Di Martino P, Le Bouder E, Hulen C, Blight MA: In vitro identification of two adherence factors required for in vivo virulence of Pseudomonas fluorescens. Microbes Infect 2003, 5(13):1177-1187.

28. Subramoni S, Nguyen DT, Sokol PA: Burkholderia cenocepacia ShvRregulated genes that influence colony morphology, biofilm formation, and virulence. Infect Immun 2011, 79(8):2984-2997.

29. Allegrucci M, Hu FZ, Shen K, Hayes J, Ehrlich GD, Post JC, Sauer K: Phenotypic characterization of Streptococcus pneumoniae biofilm development. J Bacteriol 2006, 188(7):2325-2335.

30. Lemos JA, Luzardo Y, Burne RA: Physiologic effects of forced downregulation of dnaK and groEL expression in Streptococcus mutans. J Bacteriol 2007, 189(5):1582-1588.

31. Yamanaka T, Furukawa T, Matsumoto-Mashimo C, Yamane K, Sugimori C, Nambu T, Mori N, Nishikawa H, Walker CB, Leung KP, et al: Gene expression profile and pathogenicity of biofilm-forming Prevotella intermedia strain 17. BMC Microbiol 2009, 9:11

32. Silva MS, De Souza AA, Takita MA, Labate CA, Machado MA: Analysis of the biofilm proteome of Xylella fastidiosa. Proteome Sci 2011, 9:58

33. Carzaniga T, Antoniani D, Deho G, Briani F, Landini P: The RNA processing enzyme polynucleotide phosphorylase negatively controls biofilm formation by repressing poly-N-acetylglucosamine (PNAG) production in Escherichia coli C. BMC Microbiol 2012, 12(1):270

34. Postle K, Kadner RJ: Touch and go: tying TonB to transport. Mol Microbiol 2003, 49(4):869-882.

35. Ahmer BM, Thomas MG, Larsen RA, Postle K: Characterization of the exbBD operon of Escherichia coli and the role of ExbB and ExbD in TonB function and stability. J Bacteriol 1995, 177(16):4742-4747.

36. Bagg A, Neilands JB: Ferric uptake regulation protein acts as a repressor, employing iron (II) as a cofactor to bind the operator of an iron transport operon in Escherichia coli. Biochemistry 1987, 26(17):5471-5477.
37. Blanvillain S, Meyer D, Boulanger A, Lautier M, Guynet C, Denance N, Vasse J, Lauber E, Arlat M: Plant carbohydrate scavenging through tonB-dependent receptors: a feature shared by phytopathogenic and aquatic bacteria. PLOS One 2007, 2(2):e224

38. Neugebauer $H$, Herrmann C, Kammer W, Schwarz G, Nordheim A, Braun V: ExbBD-dependent transport of maltodextrins through the novel MalA protein across the outer membrane of Caulobacter crescentus. J Bacteriol 2005, 187(24):8300-8311

39. Bhat S, Zhu X, Patel RP, Orlando R, Shimkets L: Identification and localization of Myxococcus xanthus porins and lipoproteins. PLOS One 2011, 6(11):e27475

40. Nikaido $\mathrm{H}$ : Molecular basis of bacterial outer membrane permeability revisited. Microbiol Mol Biol Rev 2003, 67(4):593-656.

41. Black PN: Primary sequence of the Escherichia coli fadL gene encoding an outer membrane protein required for long-chain fatty acid transport. J Bacteriol 1991, 173(2):435-442.

42. Moreira LM, Almeida NF Jr, Potnis N, Digiampietri LA, Adi SS, Bortolossi JC, da Silva AC, da Silva AM, de Moraes FE, de Oliveira JC: Novel insights into the genomic basis of citrus canker based on the genome sequences of two strains of Xanthomonas fuscans subsp. aurantifolii. BMC Genomics 2010, 11:238.

43. Chan YY, Chua KL: The Burkholderia pseudomallei BpeAB-OprB efflux pump: expression and impact on quorum sensing and virulence. $J$ Bacteriol 2005, 187(14):4707-4719.

44. Hong H, Patel DR, Tamm LK, van den Berg B: The outer membrane protein OmpW forms an eight-stranded beta-barrel with a hydrophobic channel. J Biol Chem 2006, 281(11):7568-7577.

45. Gil F, Hernandez-Lucas I, Polanco R, Pacheco N, Collao B, Villarreal JM, Nardocci G, Calva E, Saavedra CP: SoxS regulates the expression of the Salmonella enterica serovar Typhimurium ompW gene. Microbiology 2009, 155(Pt 8):2490-2497.

46. Princivalle $M$, de Agostini A: Developmental roles of heparan sulfate proteoglycans: a comparative review in Drosophila, mouse and human. Int J Dev Biol 2002, 46(3):267-278.

47. Hung RJ, Chien HS, Lin RZ, Lin CT, Vatsyayan J, Peng HL, Chang HY: Comparative analysis of two UDP-glucose dehydrogenases in Pseudomonas aeruginosa PAO1. J Biol Chem 2007, 282(24):17738-17748.

48. Mazar J, Cotter PA: New insight into the molecular mechanisms of twopartner secretion. Trends Microbiol 2007, 15(11):508-515.

49. Mohanty BK, Kushner SR: The majority of Escherichia coli mRNAs undergo post-transcriptional modification in exponentially growing cells. Nucleic Acids Res 2006, 34(19):5695-5704.

50. Vilain S, Cosette P, Hubert M, Lange C, Junter GA, Jouenne T: Comparative proteomic analysis of planktonic and immobilized Pseudomonas aeruginosa cells: a multivariate statistical approach. Anal Biochem 2004, 329(1):120-130.

51. Schaumburg J, Diekmann O, Hagendorff P, Bergmann S, Rohde M, Hammerschmidt S, Jansch L, Wehland J, Karst U: The cell wall subproteome of Listeria monocytogenes. Proteomics 2004, 4(10):2991-3006.

52. Caldas TD, El Yaagoubi A, Richarme G: Chaperone properties of bacterial elongation factor EF-Tu. J Biol Chem 1998, 273(19):11478-11482.

53. Siciliano RA, Cacace G, Mazzeo MF, Morelli L, Elli M, Rossi M, Malorni A: Proteomic investigation of the aggregation phenomenon in Lactobacillus crispatus. Biochim Biophys Acta 2008, 1784(2):335-342.

54. Franks $A E$, Glaven $R H$, Lovley DR: Real-time spatial gene expression analysis within current-producing biofilms. ChemSusChem 2012, 5(6):1092-1098

55. Park SJ, Cotter PA, Gunsalus RP: Regulation of malate dehydrogenase (mdh) gene expression in Escherichia coli in response to oxygen, carbon, and heme availability. J Bacteriol 1995, 177(22):6652-6656.

56. White D: The Physiology and Biochemestry of Prokaryotes. Oxford University Press 2000. Second Edition:180-207.

57. Hoffmann F, Weber J, Rinas U: Metabolic adaptation of Escherichia coli during temperature-induced recombinant protein production: 1. Readjustment of metabolic enzyme synthesis. Biotechnol Bioeng 2002, 80(3):313-319.

58. Dubbs JM, Mongkolsuk S: Peroxide Sensing Transcriptional Regulators in Bacteria. J Bacteriol 2012, 194(20):5495-5503

59. Jornvall H, Persson B, Krook M, Atrian S, Gonzalez-Duarte R, Jeffery J, Ghosh D: Short-chain dehydrogenases/reductases (SDR). Biochemistry 1995, 34(18):6003-6013.

60. Troup B, Jahn $M$, Hungerer $C$, Jahn D: Isolation of the hemF operon containing the gene for the Escherichia coli aerobic coproporphyrinogen 
III oxidase by in vivo complementation of a yeast HEM13 mutant. J Bacteriol 1994, 176(3):673-680

61. Mukhopadhyay S, Schellhorn HE: Identification and characterization of hydrogen peroxide-sensitive mutants of Escherichia coli: genes that require OxyR for expression. J Bacteriol 1997, 179(2):330-338.

62. Vlahos CJ, Dekker EE: The complete amino acid sequence and identification of the active-site arginine peptide of Escherichia coli 2-keto-4hydroxyglutarate aldolase. J Biol Chem 1988, 263(24):11683-11691.

63. Livak KJ, Schmittgen TD: Analysis of relative gene expression data using real-time quantitative PCR and the 2(-Delta Delta C(T)) Method. Methods 2001, 25(4):402-408.

64. Conesa A, Gotz S, Garcia-Gomez JM, Terol J, Talon M, Robles M: Blast2GO: a universal tool for annotation, visualization and analysis in functional genomics research. Bioinformatics 2005, 21(18):3674-3676.

65. Conesa A, Gotz S: Blast2GO: A comprehensive suite for functional analysis in plant genomics. Int J Plant Genomics 2008, 2008:619832.

66. Gotz S, Garcia-Gomez JM, Terol J, Williams TD, Nagaraj SH, Nueda MJ, Robles M, Talon M, Dopazo J, Conesa A: High-throughput functional annotation and data mining with the Blast2GO suite. Nucleic Acids Res 2008, 36(10):3420-3435.

doi:10.1186/1471-2180-13-186

Cite this article as: Zimaro et al:: Insights into xanthomonas axonopodis pv. citri biofilm through proteomics. BMC Microbiology 2013 13:186.

\section{Submit your next manuscript to BioMed Central and take full advantage of:}

- Convenient online submission

- Thorough peer review

- No space constraints or color figure charges

- Immediate publication on acceptance

- Inclusion in PubMed, CAS, Scopus and Google Scholar

- Research which is freely available for redistribution 